\title{
Banking on Union: EU governance between risk and uncertainty
}

\section{Michelle Everson, Birkbeck College, University of London}

\section{The technocratic mastery of markets}

Financial crisis and sovereign debt crisis have precipitated unexpected reform of the European Union. 2014 establishment of the European Stability Mechanism (ESM) and conclusion of the Treaty for Stability, Growth and Co-ordination (TSGC) have significantly deepened the integration basis, providing for a measure of solidarity between some, if not all member states. Necessary assistance, however, will be delivered to troubled economies within the managerial constraints of a regime of economic governance, rather than with the full redistributive blessing of a properly political union. The increasingly technocratic nature of the post-crisis regime for European monetary stability has attracted the ire of many commentators; in particular, as the strict conditionalities now imposed upon national budgetary autonomy within a framework of 'executive federalism' (Habermas 2011) have usurped traditional national democratic process, where the only available space for protest is to be found on the streets rather than parliaments of Athens, Lisbon and Madrid.

However, it would be all too easy to characterise this integration phase as a knowing period of imposition of neo-liberal models of organization upon the continent. Instead, just as sovereign debt crisis was a chronicle foretold within an original supranational sin of constitutionalized monetary restraint and abdication of political responsibility for establishment of a corollary economic steering policy within Economic and Monetary Union (Majone 2014), EU political design is still convoluted by lacking national consensus and the absence of a constitutively-redistributive European will. Seen in this light, deepened technocratic structures to combat crisis also reflect the default position within contemporary socio-economic organisation, or a 'permissive consensus' (Crouch 2011), which, post political ideology, posits its own universal legitimation within the maximised welfare gain furnished by the marriage between governance techniques and the science of new economic liberalisms.

Permissive consensus - a global trend extending far beyond the EU - has silently overturned the post-war, tax-based, redistributive settlement, placing its faith instead in a 'futurization' paradigm (Esposito 2013 \& 2014), wherein the contingent opportunities created within postulated economic growth compensate for state welfare withdrawal (Crouch 2011). Within this context, technocratic governance is not simply legitimated by recourse to expertise, but is instead lent inspirational utilitarian force by pursuit of welfare maximization, and an underlying belief that economic steering 
capacities - concerned also with securing public goods - can still be exercised by the executive, but must now be so in heterarchical rather than in hierarchical forms (Vibert 2011). The sine qua non of contemporary governance as it substitutes for representative democracy is its flattened pursuit of universal welfare gain within the optimized allocative efficiency of private markets. For peripheral Eurozone economies, the doctrine of welfare maximization translates into the futurizing maxim that 'following pain will come gain,' as imposed austerity is geared to structural reform, which, it is asserted will eventually unleash the healing powers of privately-initiated economic growth. For private markets, however, this self-same precept creates a paradox of executive promotion of a competitive market paradigm, which is nevertheless far too important in its social utility to be left to be governed by market processes alone.

The far too often overlooked component within the spread of governance regimes is their dual impact, first upon a public sphere of democratic self-expression, but secondly also upon a private economic realm. Just as democracy cedes to technocracy, autonomous market exchange is overwhelmed by expert imposition of a utility model, which seeks to perfect competition. Nowhere is this fact - and the oversimplified nature of contemporary critique of neo-liberalism - more apparent than in the case of European response to financial crisis, and, in particular, in the example of the corollary to restraint of national sovereign debt: the control of private money creation, or accumulation of debt, within European Banking Union. Established by the Single Supervisory Mechanism (SSM) and Single Resolution Mechanism (SRM), ${ }^{1}$ European Banking Union has, as its primary function, the combatting of the systemic risk - defined, in this case, as the transmission of bad debts within European financial markets - which, as member states were forced to issue unlimited banking guarantees, precipitated sovereign debt crisis. Nevertheless, the provision to the European Central Bank (ECB) of enhanced supervision powers over the Eurozone banking market should also be examined within a far broader context; first of long-standing global revolution in the purpose of financial services within all advanced economies, and, secondly, in the recent light of the end of the 'Jackson Hole consensus..[.]..that price stability is sufficient condition for financial stability' (Born et al 2012:186).

Following hard upon the 2010 creation of the European System for Financial Supervision (ESFS), including establishment of the European Banking Authority (EBA) and European Systemic Risk Board (ESRB), Banking Union must be viewed against the backdrop of an unprecedented strengthening of

\footnotetext{
${ }^{1}$ Council Regulation (EU) No 1024/2013 of 15 October 2013 conferring specific tasks on the European Central Bank concerning policies relating to the prudential supervision of credit institutions and Regulation (EU) No 1022/2013 of the European Parliament and of the Council of 22 October 2013 amending Regulation (EU) No 1093/2010 establishing a European Supervisory Authority (European Banking Authority) as regards the conferral of specific tasks on the European Central Bank pursuant to Council Regulation (EU) No 1024/2013.
} 
the regulatory and supervisory framework for all European financial services, including insurance, banking and credit markets inside and outside the Eurozone. ${ }^{2}$ Where it completes the dense web of executive oversight of private capital maximization within Europe, Banking Union similarly apportions the by-now lynchpin role of co-ordination of micro-prudential and macro-prudential supervision within European financial markets to the ECB, re-inventing the Bank both as a sectoral supervisor for the Eurozone banking market (micro-prudential function), and as a final oversight authority for EU financial stability (macro-prudential function). This assumption by the ECB of a dual responsibility for monetary and financial stability, is similarly part of a global trend, whereby central banks have increasingly been called upon to exercise additional macro-prudential functions (Born et al 2012); a trend, which, post crisis, comprises only the final stage in long-standing executive efforts to harness, but also to master the competitive benefits of liberalised capital markets.

Heralded by the 'Big Bang' of 1980s deregulation of UK capital markets, global liberalization has placed private finance at the very core of the futurization paradigm, wherein capital maximization through the multiplication of the usages of money - or of its 'dual-disposition' as debt and credit (Heffernan 1995:161) - provides both immediate gain and, under efficiently competitive conditions of financial innovation, optimized future opportunities for economies and citizens alike. Crisis has not ended this dependence upon 'privatised Keynesianism' (Crouch 2011), and might even be argued to have hardened it, as enhanced supervisory oversight of financial markets now serves a dual purpose of promoting competitive utility on the one hand, but also of ensuring, on the other, that market dysfunction cannot interrupt futurized provision of public welfare through private markets.

Where the crisis-driven recognition that a revolutionised financial system also poses dangers to futurizing growth, such that the primary regulatory aim has become the final perfection of market utility by means of control of systemic risk, the ECB now sits at the apex of a system of paradoxicallypermissive interventionism, which, it is postulated, can both maximize capital formation and provide financial stability. This Chapter investigates this proposition, detailing first how conflicting goals of capital maximization and financial probity are seemingly reconciled within a regime of 'reallyresponsive' supervision (Baldwin \& Black 2010) dedicated to the maintenance of 'sound European money'3 (II). Thereafter, the analysis details the global and EU-specific problems found within permissive interventionism, whereby further efforts to square the circle of secure competition

\footnotetext{
${ }^{2}$ Comprising Regulation (EU) No 1092/2010 (ESRB Regulation); Regulation No 1096/2010 (ECB/ESRB Regulation); Regulation (EU) No 1095/2010 (ESMA); Regulation (EU) No 1093/2010 (EBA), and Regulation (EU) No 1094/2010 (EIOPA).

${ }^{3}$ Teubner (2011), summarizing recent works of economic theory.
} 
within structures of what can be termed 'democratized technocracy' (III), create their own hazards, once again placing the future of the European Union in doubt (IV).

\section{Squaring the circle with sound money}

ESFS and Banking Union constitute an unparalleled remodelling of EU economic oversight competences over private markets. The EBA, together with its sister agencies (ESAs), the European Authority for Insurance and Occupational Pensions (EIOPA) and the European Securities and Markets Authority (ESMA), is one of the most powerfully-autonomous agencies ever to emerge at EU level, wielding unprecedented regulatory competences, as well as previously-unknown intervention powers at national level (Moloney 2010). At the same time, and beyond the new scheme of positive regulation for EU financial services markets, the ESFS and Banking Union have also created a regime for the governance of European money that gives unmatched discretionary powers to expert supervisors (Andenas \& Chiu 2013). In part, this new governance comprises soft powers, as the ESRB Board, chaired by the ECB President, ${ }^{4}$ pursues a macro-prudential role of preserving overall EU financial stability by alerting actors within the ESFS to the existence of systemic risks within markets. Eurozone governance, nonetheless also hardens as the ECB exercises micro- and macro-prudential oversight powers within the SSM, and the new Single Resolution Agency (SRA) acts under the umbrella of Commission competence with regard to the resolution or winding up of bad banks.

Importantly, however, for all of its innovative features, the crisis-driven emergence of a governance regime for EU money cannot be viewed as a European peculiarity, specifically designed to combat the spill-over effects that prompted cross-border melt-down. Instead, it is also a part and logical continuance of an established global regime of technocratic governance for banking and financial services. Created in 1974, the Basel Committee of banking supervisors and central bankers has long exercised influence over worldwide banking regulation, ${ }^{5}$ playing its vital part in structured market liberalization, more particularly, in its efforts to define the nature of permissible national 'prudential supervision' within the ambit of World Trade Organisation (WTO) free trade strategies. ${ }^{6}$ Where the Committee is currently engaged in the urgent endeavour to combat global systemic risk, ${ }^{7}$ the new European regime is part of a wider movement which aims to establish an oversight framework for promotion and mastery of global competitive revolution.

\footnotetext{
${ }^{4}$ And made up of national central bank governors, a Commission representative and the Chairs of the three ESAs; see ESRB regulation, note 1 above.

${ }^{5}$ See, for details: www.bis.org/bcbs/about.htm

${ }^{6}$ General Agreement on the Trade in Services, Annex on Financial Services (2)(a).

${ }^{7}$ See, the activities of the Financial Stability Board, established in 2009, by the G20 group of nations (www.financialstabilityboard.org/about/overview.htm).
} 


\section{The risks of revolutionary futurization}

'The movement, management and pricing of risk have moved from the periphery to the core of financial activity' (Borio \& Zhun 2012:251): where the same might be said of oversight regimes, the commonplace observation that revolutionary change in the global economy was precipitated by deregulation of financial services markets must be qualified. Vitally, in the case of banks, the term 'deregulation' is a misnomer, as worldwide release of banking from straitjackets of strict investment controls (prudential supervision), as well as from innovation-restraining material supervision (product approval), was based, not upon a rejection of regulation, but rather upon its technical perfection. That is, upon its rebirth in the risk-based supervision of the capital adequacy and governance of banks, as well as, to a lesser degree, in new regulatory frameworks - built upon the quality of advice given by financial intermediaries - designed to transform once paternalistic conceptions of consumer protection into competitive models of consumer choice. ${ }^{8}$ In the case of financial services, less has paradoxically meant more within a technical regime of permissive interventionism, wherein regulation and - far more importantly - enhanced supervisory capacity is dedicated to pursuit of market utility.

New technologies of micro-prudential banking regulation are founded within a core conviction that the ever-present leverage risks posed by banks can be managed in a market-friendly manner that eschews pre-emptive imposition of regulatory solvency margins for capital adequacy beyond that which is necessary to establish basic confidence. Instead, in addition to a minimum capital requirement, regulators and regulated work in tandem in order to establish capital adequacy margins that reflect the true market position of each organization, or the risks posed by its liabilities relative to its assets. In turn, the technique of market-conform, or economic solvency is not simply concerned with ensuring that banks are safe (Heffernan 217-266). Rather, where the assessment of the soundness of a firm is measured with reference to its real rather than postulated market exposure, personalized capital adequacy, tailored to commercial strategy, has a second function of promoting a competitive market discipline, within which the strong may be distinguished from the weak, and competitive choice is the norm.

Importantly, however, pursuit of market utility is not limited to banks. Instead, the permissiveinterventionist creed has been pursued across global financial markets, creating new problems and prospects for private banks. A post-war sector that lagged far behind the goods market in terms of

\footnotetext{
${ }^{8}$ This is approach is most advanced within UK regulatory structures and is now similarly complemented by the supervisory application of the discipline of behavioural economics, with the specific aim of maximizing consumer utility: Financial Conduct Authority, 'Applying Behavioural Economics at the Financial Conduct Authority,' Occasional Paper No.1, available at: www.fca.org.uk/static/documents/occasional-papers/occasional-paper-1.pdf (accessed March 2014).
} 
competitive growth (Heffernan 1996: 123-160) has faced significant challenges to its dominant position in the efficient allocation of money. At the same time, however, it has also begun to reassert its own profitability within new patterns of heightened futurization opportunity. The core facilitating transformation resides in comprehensive change in the nature and role of money within the broader economy, and, in particular, in the multiplication of its present and future uses. Where banks once paddled quietly in the backwaters of intra-institutional and inter-institutional lending, the multiple risks associated with the double-disposition of money, or its simultaneous existence as a debt and a credit, were subject to in-house management. The various risks associated with the two primary challenges faced by banks - default between creditors and debtors and maturization mismatch between monies lent and monies earned - were tackled in a pedestrian manner on the basis of superior information about the moral hazard posed by customers, as well as relative expertise with regard to the prediction of interest rate and pricing movements.

Upon Big Bang, the sector faced an existential challenge to its competitive dominance, firstly in the mastery of informational asymmetries between creditors and debtors, and thereafter in the maximization of capital value for the general economy. Where regulatory liberalization, rapid technological advances, globalization and increasing refinement of financial products facilitated heightened differentiation of the exogenous and endogenous risks posed to lending operations, it created its own myriad and distinct risk pools, thus increasingly substituting the quantitative risk modelling of global capital markets for the largely subjective risk assessments undertaken within banking firms. ${ }^{9}$ As global hazards of interest-rate risk, exchange-rate risk and sovereign-default risk were separated out from the bank-internal lending dangers of settlement and payment risk, operational risk and market and price risk, to be sold within myriad financial instruments, the exponential multiplication of the dual-disposition of money, founded in the creation of a new contractual market for the management of individuated risks, became its own futurizing reality. Innovative financial instruments, such as over-the-counter derivatives, credit-default swaps and securities, and legion futures, provided a simultaneous means of packaging out and managing the leveraging risks associated with lending, at the same time multiplying the availability of present and future monies within capital markets.

Allowing economies, as well as individual lives to be managed in expectation of constant capital gain, futurization nevertheless called into question the profitability of traditional banking models, characterised by the strict regulatory divisions made between retail and investment banking, or

\footnotetext{
${ }^{9}$ For exhaustive details, see Heffernan (1996). Briefly: new financial instruments seek to mimic traditional insurance risk pools, bringing together similar risks in order to allow for establishment of an averagely affordable price for contractual risk-management (though without reference to actuarial data).
} 
between a once distinct public interest in day-to-day financial settlements and more speculative investment activities. With the state retreat from widespread welfare provision, the multiplication of money usage has perhaps become the drug with which the global economy cannot do without, implicating all citizens in immediate gratification, as well as the expectation of financed future opportunity. At the same time, however, modern micro-prudential regulation, as well as a still powerful post-crisis interest in combined retail and investment banking, ${ }^{10}$ incentivizes and enables the banking sector to play its own important role within capital maximization. The parallel to the waning profitability of traditional banking models is equal participation of banks within the futurization paradigm, or within the solvency-conform spread of banking sector risks across global financial services markets. Where banks are also free to innovate, moving beyond internal risk management, in order to securitize and offset lending risks within the highly differentiated products of financial innovation, they may now, on the one hand, pose and be exposed to a systemicallyrelevant risk of counter-party default, whereby, for example, securitized assets have been revealed as worthless vessels of bad debt. At the same time, the sale of individuated risks on global markets, offers up a shareholder-value-securing promise of increased competitive efficiency, ${ }^{11}$ as banking liabilities are transferred from balance to trading accounts, becoming assets to be managed in contractual operations by individual counterparties with the greatest proven degree of success in individuated risk management (Heffernan 1996).

\section{Governing futurization}

In the view of some, 'recent events' - financial crisis - 'show that financial innovation is of limited value relative to the risks engendered (Garicano \& Lastra 2010:7). The observation captures the painful irony of financial crisis. The financial instruments within which bad debt had been dissipated, only to re-emerge with disastrous consequences as faith in US mortgage securities collapsed, may not simply be dismissed as the unconscionable creations of commission-obsessed bank employees. Bad banking practices have quite rightly met with a tsunami of criticism: above all, where the ready provision of mortgage facilities to peripheral economic actors within the US was presented as an act of economic democratization, or an extension of futurization benefits to the underprivileged, the creation of a risk pool of poorer citizens newly incentivized towards indebted behaviour, simultaneously created the conditions for the systematic expropriation of the few resources over

\footnotetext{
${ }^{10}$ See, for the poor prospects of an end to 'universal' banking, evidence (Rosa Maria Lastra) to the House of Lords Report on the Future or EU Supervision and Regulation (2009), available at: www.parliament.uk/business/publications/house-of-lords-publications

${ }^{11}$ Added-shareholder-value is a new measure of the profitability of banks reflecting the competitive nature of revolutionary banking environment. Previously, the health of the sector was assessed relative to its assetsliabilities balance. See Heffernan (1996:123-160).
} 
which this grouping disposed (Block 2013). At the same time, however, such products not only also came into being as advanced risk management tools within financial markets, but were similarly largely congruent with the regulatory philosophy developed by a global executive dedicated to perfection of innovative competition.

Much has likewise been written about the role of banking regulation, and in particular, the Basel II Accords, in precipitating crisis. Most strikingly, a much celebrated Value-at-Risk methodology (VaR), designed to ensure the security of market investments by requiring banks continuously to calculate their real-time market exposure has been identified as encouraging the pro-cyclical behaviour of the sector, or its over-leveraging on the back of rising markets within which securitized assets were subject to overvaluation, such that capital adequacy proved illusionary (Black 2010). At a deeper level, however, and writing shortly prior to crisis (Sappideen 2004:61), one commentator unwittingly captured the fundamental paradox associated with contemporary banking regulation. Under the impetus of futurization, the 'regulating of risk within the banking sector' could not and should not interfere with the competitive paradigm. Instead, recognition 'of the vibrancy and necessity of financial innovation' remains uppermost, with the consequence that the success or otherwise of a primary micro-prudential goal to, 'at the same time limit, if not prevent, the downside of bank failure' (Sappideen 2004: 61), resides in adoption by bankers and regulators of a responsively interactive supervsors paradigm in which the mutual refinement of risk management takes central stage (Black 2007).

In crisis, the sector was accordingly bolstered in its overdue reliance on market-based securitization by its particularly close relationship with supervisors; an intimate partnership that fostered the catastrophic joint 'cognition failure' that failed to appreciate that individual risk management strategies created systemically-relevant risks (Black 2010). Nevertheless, 'the essential' - in crisis, fatal - 'linkage between banks and their supervisory authorities' (Sappideen 2004:61), or their jointly calibrated response to leveraging risks, remains at the core of the Three Pillar supervisory structure introduced by Basel II and retained in post-crisis Basel III Accords, as banking supervisors continue to engage in a continual process of identification of the exact categories of risk which impact upon the multiple usages of money, to then re-engage with the market: first, overseeing the advanced economic modelling deployed by the sector to establish their own risk-off-setting capital adequacy barriers, albeit subject to higher regulatory capital and liquidity requirements (Pillar One); secondly, encouraging the establishment of sector-internal governance structures which are also sensitive to newly revealed risk (Pillar Two); and, thirdly demanding adequate disclosure in order to 
secure market disciplines which ensure the efficiency and innovative character of bank operations (Pillar Three).

\section{Systemic risk, macro-prudential oversight and the post-crisis EU response}

Futurization is the paradigm that refuses to die; at least to the degree that risk-based supervision remains the preferred means to oversee, but also to sustain innovation. The emergence of systemic risk within financial markets - for which 'there is no universally accepted definition, let alone an accepted measure of quantification' (Arnold et al: 2012: 3127) - is a new phenomenon, whose exact causes and ramifications are as yet only dimly perceived in economic literature (Siklos 2011; Born et al 2012). Nevertheless, where, in the minds of policy-makers, systemic risk equates with financial instability 'so widespread that it impairs the functioning of a financial system to the point where economic growth and welfare suffer materially,' ${ }^{12}$ 'waiting was not an option,' such that 'policies have moved ahead of academic research' (Arnold et al 2012:3127). Basel III accordingly dedicated itself to correcting volatility-inducing Basel II prescriptions, in order to ensure that 'banks are 'shock absorbers rather than risk transmitters' in the face of 'volatile market conditions, or worse still in the time of financial crisis,' (Lee 2013:434 ). However, in seeking also to transform financial markets into future guarantors for the global economy, Basel technocrats similarly balanced hardened regulatory strictures, in particular in the matter of heightened minimum capital and liquidity requirements, against continuing faith in the effectiveness of supervisory oversight of market utility; albeit that the relationship between regulator and regulated has now been restructured in order to afford overseers greater powers to tailor core market operations to the need for stability.

Given the role played by the close marriage between the industry and supervisors in crisis, renewed Basel faith in an enhanced supervisory role, not only in routine matters of identifying the risks posed by the form in which capital is held and debt is dissipated, but also in the technocratic oversight of rating agencies, the application of stress tests and the setting of additional countercyclical capital buffers and leverage ratios in times of credit growth (Lee 2013: 440-442), may and does appear incongruous. Yet, on the one hand, where a new supervisory fulcrum of macro-supervision remains as ill-defined as the systemic risk it is designed to combat (below III), the discretionary rather than prescriptive character of supervision, just as surely allows for continual corrective adjustment in the oversight function (Siklos 2011). Meanwhile, and perhaps far more critically, where 'the ultimate goals of the policy are still the usual macro-economic ones of output and welfare,' (Arnold et al 2012:3132) post-crisis oversight schemes remain wholly in obeisance to permissive-interventionism.

\footnotetext{
12 Jean-Claude Trichet, then ECB Chair, 2010, $13^{\text {th }}$ Conference of the ECB-CFC Research network; cited by Arnold et al (2012:3127).
} 
And so too at EU level, where Basel III technical recommendations, ${ }^{13}$ as well as its creed, are reproduced in a dual strategy of hardened regulatory competence on the one hand, and establishment of 'really-responsive' (Baldwin \& Black 2010) governance on the other, wherein oversight responds to the systemic risks posed by liberalization by means of soft co-ordination of the purposes of micro- and macro-prudential regulation within the ESRB and Banking Union.

\section{ESFS and the hardening and deepening of EU competence}

The ESFS, established in 2010, was not the first endeavour to co-ordinate financial supervision at supranational level, building instead upon the regulatory principles, national networks and European standard-setting committees, established in the wake of the report of the Lamfalussy Committee of Wise Men on the Regulation of European Securities Markets in early $2001 .{ }^{14}$ A creature of the executive-led revolution in global financial services markets, Lamfalussy busied itself with inducing a globally-competitive orientation within EU markets. Unwieldy EU regulation and discrepancies in national implementation were then viewed as regulatory failings, not because they accentuated informational asymmetry, but rather since they retarded adaption of European financial services 'to the pace of global financial market change. ${ }^{\prime 15}$ By rhetorical contrast, the high-level de Larosière group, convened in response to crisis, seemed to return to a traditional concept of market failure: where the existing system disposed over an 'inadequate mix' of regulatory and supervisory skills and had failed to register the 'the global magnitude of global leveraging,' its failure to 'fully understand or evaluate the size of the risks,' must now be corrected by means of strengthened European regulation, designed to entrench improved supervisory management of informational asymmetries and to create 'a co-ordinated early-warning system to identify macro-systemic risks of a contagion of correlated horizontal shocks. ${ }^{16}$

Most commentators agree that regulatory arbitrage within the less intrusive Lamfalussy system weighed most heavily in favour of the unexpected hardening of the supranational supervisory competence (Snowdon \& Lovegrove 2010; Andenas \& Chui 2013). The preparedness of member states to manipulate residual national regulatory competence in order to assert their varying degree

\footnotetext{
${ }^{13}$ See, for example, The Capital Requirements Directive (CRD III), 2010/76/EU (OJ L329/3 of 12.10.2010), and the Solvency Directive for Insurers (Solvency II), 2009/138/EC (OJ L 335/1 of 17.12.2009). The Securities Regulation on Credit Rating Agencies (Regulation (EC) No 1060/2009), the Directive on Alternative Investment Funds (Directive 2011/61/EU, OJ L174/1, of 01.07.2011), as well as proposed regulation on over the counter derivatives and short-selling: $\operatorname{COM(2010)484/5}$ and $\operatorname{COM(2011)482.~}$

${ }^{14}$ Known as the European Financial Services Action Plan (Commission Decisions, 2001/527/EC and 2001/528/EC (EU Securities Committee and Committee of European Securities Regulators); Commission Decision 2004/10/EC (Committee of European Banking Supervisors; Commission Decision 2004/9/EC (Committee of European Insurance and Occupational Pensions Supervisors)).

${ }^{15}$ http://ec.europa.eu/internal_market/securities/docs/lamfalussy/wisemen/final-report-wise-men_en.pdf

${ }^{16}$ http://ec.europa.eu/internal_market/finances/docs/de_larosiere_report_en.pdf
} 
of tolerance for the risks posed by financial markets (Andenas \& Chui 213) undoubtedly played its part in crisis-inducing contagion. Nevertheless, at least to the degree that arbitrage created its own particularly obdurate competition barrier, crisis has also provided further opportunities for permissively-integrative interventionism within European markets in line with global trends. Hardened regulatory prescriptions apart, the ESFS is also a responsive creature of market utility: the three European Supervisory Authorities (ESAs), led by specialist national regulators and shielded from political influence, have been inserted into the existing supervisory paradigm, wherein they are charged with unavoidably conflicting roles of 'improving the functioning of the internal market', 'ensuring the integrity, efficiency and orderly functioning' of markets, combatting 'regulatory arbitrage' and securing 'consumer protection' ${ }^{17}{ }^{\mathrm{ESAs}}$, with their dual rule-making and supervisory function now find themselves on the discretionary front line of simultaneous promotion of innovation and security within financial markets. Given the key role of elaborating the new EU legislation which implements Basel III, ${ }^{18}$ ESAs have also accrued unprecedented supervisory powers, including, controversially (Moloney 2010), emergency intervention powers in national financial instruments markets, where informational asymmetries threaten financial stability (MifiD $\mathrm{II}^{19}$ ).

\section{Banking Union and the governance of sound money}

This final focus of the ESFS upon financial instruments is telling: a critical futurization tool, the movement of the banking sector beyond its traditional role of mediating informational asymmetry to engagement within a contractual market for the management of differentiated risk (Sapideen 2013), finds its corollary in heightened informational asymmetries and thus also in dangers of the spread of poor quality money. This, in turn, creates a new site for prudential supervision in the reestablishment of control over the multiplication of monies by critical players within markets: an operation which demands, on the one hand, that micro-regulatory interventions allowing innovative financial instruments to enter the market must also be assessed for their macro-economic impact; and, on the other, requires a far broader, liquidity-based assessment of market-based leveraging. Revolution within financial services has created its own endemic risks, to which the really-responsive paradigm of co-ordinated micro- and macro-prudential regulation is a rejoinder. Nevertheless, the technocratic quest for sound money - a concomitant final transformation of the character of the overseer from shadowy regulatory presence beyond the firm to tangible presence within it - is

\footnotetext{
${ }^{17}$ Article 1 of the ESMA, EBA and EIOPA Regulations, see note 2 above.

${ }^{18}$ In elaboration of framework Directives for European financial services markets. Mirroring old-style comitology procedures and in accordance with Article 290 TFEU, the EBA drafts BTS which are given legal force as Commission Implementing Acts.

${ }^{19}$ Directive on markets in financial instruments, Directive 2014/65/EU (MiFID 2) repealing Directive 2004/39/EC and the Regulation on markets in financial instruments (Regulation (EU) No 600/2014 on markets in financial instruments).
} 
wrapped in uncertainty: on the one hand, in the institutional uncertainties that characterise a still evolving technique of macro-supervision; on the other hand, and specifically so in the EU context, in the political uncertainties of an as-yet-to-be negotiated relationship between Banking Union and the integrated market.

Like its ESFS counterpart, Banking Union is shaped by its preoccupation with perfected competition. The ECB is obliged by Article 3 of the SSM Regulation to pursue 'economic growth' in the 'integrated market'; a generalist obligation, which itself translates into a very specific Commission goal:

Banking Union 'will put an end to the era of massive bailouts paid for by taxpayers and will help restore financial stability. This, in turn, creates the right conditions for the financial sector to lend to the real economy, spurring economic recovery and job creations. ${ }^{20}$

Banking Union - and likewise the Single Resolution Mechanism ${ }^{21}$ - is designed to promote a marketdriven exit from crisis. At the same time, however, it is a leap into the unknown. Co-ordinated central bank pursuit of micro- and macro-prudential goals is not a given (see, also, below III): above all, in many national settings, 1980s liberalization also found its corollary in re-allocation of banking supervision powers away from central bankers to autonomous agencies, not only as a demand for specialist oversight grew, but also as the newly apportioned competences of central banks to set interest rates were perceived as being in conflict with micro-economic oversight, impacting upon sectoral informational asymmetries, and thus, where rates fluctuate, distorting the primary risk management process of asset-liability accounting (Heffernan 1996; Claeys \& Schoors $2007^{22}$ ). At the same time, where nascent worries - albeit as yet under-researched - have emerged about the distorting realities of a financial circle (Arnold et al 2012), as well as about the impact of risk-based innovation models upon existing understandings of the 'transmission mechanism', or relationship between monetary policy and the general economy (Borio \& Zhu 2012), the technocratic oversimplifications of Basel III are revealed; the postulation of an 'equilibrium credit', or simple measure of leveraging to national GDP, which triggers automatic instability-busting pro-cyclical buffers, ${ }^{23}$ is unmasked as a complex formula, reliant for its effective operationalization upon the discretional decisional capacities of technocrats.

\footnotetext{
${ }^{20}$ European Commission Memo (Brussels, 15 April 2014) Banking union: restoring financial stability in the Eurozone. Available at: ec.europa.eu/internal_market/finances/docs/banking-union/banking-union-memo_en.pdf.

${ }^{21}$ Which, according to the Commission, will end the 'serious fragmentation of the Single Market in lending and funding' which 'impeded efficient lending to the real economy and thus growth,' ibid n 21.

${ }^{22}$ For contemporary evidence on the apparent incongruity of macro- and micro-prudential goals (within the Russian model).

${ }^{23}$ See Bunclic \& Melecky (2014).
} 
In its introduction to Banking Union (COM(2012)511), the Commission underlines its apparent belief in the pareto-efficient character of European regulation: 'Monetary policy tasks [of the ECB] will be strictly separated from [its] supervisory tasks to eliminate potential conflicts of interest between the objectives of monetary policy and prudential supervision.' Doubted even by supporters of efficient regulation - particularly for money management, which is argued always to possess a redistributive dimension (Majone 2004) - the Commission's technocratic isolationism is immediately undone, within the highly discretionary character of ESFS and SSM governance structures. Where the necessarily complex nature of the search for sound money - at core a matter of trade-off between competitive and prudential goals within financial markets and the economy - is accepted, the demand for discretion overwhelms regulatory strictures. Hence, soft governance within the ESRB, where the Board has no powers of its own and is instead dependent upon its constituent members to combat systemic risk (Ferran \& Alexander 2010). Hence, however, also the peculiar structures of Banking Union.

Charged with the direct micro-prudential supervision of 'significant' Eurozone banks, defined by their size, importance, and volume of cross-border activities (Article 6 SSM Regulation), and required to act within a framework of macro-prudentially-oriented oversight, in which it may apply contagionbusting mechanisms, such as heightened capital adequacy buffers (Article 5 SSM Regulation), the $E C B$ is the lead actor in the squaring of the circle between welfare-maximizing efficiency and financial stability in the Eurozone. A first indication of inevitable conflict within this function thus predictably arises with regard to potential mismatch between the Bank's monetary and sectoral competences: finding their most striking expression in the Chinese walls erected between the ECB's prudential and monetary functions - whereby prudential functions are delegated to personnel who are 'organisationally separated from, and subject to, separate reporting lines from the staff involved in carrying out other tasks conferred on the ECB' (Article 25(2)) - technocratic efforts to divide monetary and sectoral policy are simultaneously revealed to be illusory. Separation is not absolute but rather co-ordinated by means of a Mediation Panel (Article 25(5) SSM Regulation), which shall 'resolve differences of views' between 'participating Member States regarding an objection of the Governing Council [responsible for monetary policy] to a draft decision by the Supervisory Board [responsible for prudential regulation].' Constituted by a member from each participating Member State, chosen from Governing Council and Supervisory Board members, and reaching decisions by simple majority, the Panel of - in effect - central bankers would appear to be characterised less by strict judicial-type adjudication and more by belief in the rational power of experts to reach informed accord in the face of incompatible policy objectives (Joerges \& Neyer 1997). 
This credo of softly 'deliberative governance' - and respect for national expertise - is likewise reproduced in discretion-extending form throughout the SSM. The Mediation Panel will also deliberate in cases where ECB micro-prudential activity appears to conflict with its macro-prudential role within the ESRB (Article 25(1) SSM Regulation). Likewise, Article 6(1) SSM Regulation pledges that ' $[B]$ oth the ECB and national competent authorities shall be subject to a duty of cooperation in good faith, and an obligation to exchange information;' a particularly important assurance where the ECB is also charged with carrying out supervisory review on national soil (Article 4 SSM Regulation). Further, national allegiance to the SSM is secured in the composition of the Supervisory Board, responsible for management of SSM tasks, which is made up of representatives of the ECB and national central banks (Article 26 SSM).

This rupture in traditionally strictly-circumscribed powers of executive oversight might be justified by the dedication of discretionary governance to the re-establishment of the sovereign competence of central banks to create money. Nevertheless, within the broader EU setting, establishment of a discretionary Banking Union framework is prescribed by the additional tensions of heightened European differentiation, or by potential incompatibility between the interests of member states who are and who are not participating within the SSM. The SSM Regulation and amended EBA Regulation therefore also create a series of governance safeguards both to protect the co-operative nature of EBA-ECB relations and to address the concerns of non-participating member states. The EBA retains its remit as sectoral regulator for the whole of the EU, creating an immediate tension arises between ECB and EBA functions in the matter of differentiated rule-making for the Eurozone and internal market, which is similarly mediated by restatement of the once contested principle that the ECB is now subject to Union law (below III), and must exercise its powers to issue regulations (Article 132 TFEU) with full respect for EBA competences to draft technical standards, guidelines and recommendations to ensure supervisory convergence: ' [T]he ECB should not replace the exercise of those tasks by the EBA' (Recital 32 SSM Regulation). More complex, however, is the issue of overlap in ECB and EBA supervisory tasks, especially as regard on-going efforts to establish the day-to-day methodological mechanics of supervisory oversight where the integrated markets overlaps with Banking Union. Here, however, a deliberative relationship is similarly envisaged between the experts of each authority by Article 3 of the Regulation which stipulates a 'co-operative' partnership.

Potential strains in ECB-EBA relations due to the difficulties of the co-ordination of the interests of participant and non-participant members are given further attention in relation to EBA operation, where the fears of non-participant states that their views will fall victim to majority voting in the 
Supervisory Board have been countered with an amendment to its Founding Regulation. ${ }^{24}$ Where once simple majority voting was the rule, the majority of EBA tasks, such as the preparation of BTS will now be subject to qualified majority voting. Only in cases of emergency or breach of EU law will voting return to a simple model. ${ }^{25}$ Within the SSM itself, further safeguards are also envisaged for non-members, who may conclude memoranda of co-operation with the ECB, but may subsequently object to a draft decision of the SSM Supervisory Board, which is firmly enjoined to act in the 'interests of the Union as a whole' (Recital (72) SSM Regulation), and to ensure the 'openness and transparency' of the mechanism (Recitals 10 \& 14 SSM Regulation).

\section{Squaring the circle within democratized technocracy}

In optimistic analysis, response to crisis has not challenged the political neutrality of the futurization paradigm. Notwithstanding the 'novelty' of macro-prudential regulation (Geva 2013:408), discretionary squaring of the circle of sound money remains a wholly technocratic exercise as potential conflict between sectoral and general economic policy dissolves within the simplicity of really-responsive regulation, wherein '[m]acro-prudential regulation', concerned with 'interactions between financial institutions, markets, infrastructure and the wider economy [.] complements the micro-prudential focus on the risk position of individual institutions, which largely takes the rest of the financial system as a given;' albeit that 'neither type of policy is a substitute for' sound private sector risk management, which should 'internalise the risk of potential losses' (Joosen 2010:49826). Optimism extends even to the balancing of monetary and prudential supervision at whichever level it might arise. Where micro-supervision concerns itself with 'endogenous risks' to stability, posed by the 'collective behaviour of financial institutions,' where 'financial crises are not an act of God,' but the outcome of 'systemic distortions in perceptions of risk and responses to it' (Geva 2013:409), and where macro-supervision tackles risks 'exogenous' to the sector, in particular, temporal pro-cyclical biases $^{27}$ - themselves closely related to overall liquidity levels dictated by monetary policy - pursuit of financial stability through alignment of endogenous to exogenous risks places macrointerventionism in a 'land between monetary policy and supervision' (Geva 2013:41028). However, as no lesser body than the Bank of International Settlement has argued, the lynchpin role that is now to be played by central banks in addressing 'the close two-way relationship between .[.]. pro-cycliality

\footnotetext{
${ }^{24}$ See note 2 above.

${ }^{25}$ Including simple majorities of participating and non-participating members, Article 41 , paragraphs 2,3 \& 4 Amended EBA Regulation, see note 1 above.

${ }^{26}$ Citing the Co-ordinating Committee on the Global Financial System of the Bank of International Settlements.

${ }^{27}$ Note that systemic hazard may also be situational, whereby risks are concentrated upon one area of the market (Geva 2013:409).

${ }^{28}$ Citing Tommaso Padoa-Schioppa.
} 
and conducting monetary policy' is similarly legitimated by technical expertise, or their 'deep experience in system-wide analysis and intervention.'

Others are far less sanguine:

[A] central bank is not an appropriate institution for macro-prudential supervision because central bankers are not legitimate politically to make decisions that involve important tradeoffs between political and economic objectives [.] [S] uch decisions should be left with finance ministries and other elected officials (Ferran \& Alexander 2010:771).

This lesser faith in the technocratic legitimacy of central bank steering capacity reflects the view that the pursuit of sound money is far less a value-neutral squaring of the circle between innovation and stability, and far more an abdication of political responsibility for the consequence-laden decision to curb or to facilitate futurization. As the historical arbitrage which bedevilled the Lamfalussy system amply demonstrates, variations in risk appetites do exist, in this particular case between member state governments, and are just as much demonstrative expression of the political nature of tradeoff between lost opportunity gains and immediate, if utility-dampening security, as of a desire to protect national markets.

Within economic literature, growing sensitivity towards the political complexities of the pursuit of sound money is reflected in studies, which, at their most optimistic, highlight the 'reputational risks' (Born et al 2012:180) posed to central banks by assumption of macro-prudential functions; likewise fearing, at their pessimistic worst, that politicisation of the central bank function may eventually overwhelm technocratic independence: '[o]ne can reasonably ask whether, having won the battle to maintain central bank independence, some central banks may in the future lose the war, if and when the next crisis emerges' (Siklos 2014:7). Within the specific context of the EU, growing political complexity is also apparent within the endeavour, however indistinct, to democratize exercise of technocratic discretion within Banking Union.

\section{Democratized administration}

Three decades ago, Claus Offe was drawn to note that: '[b]ehind the façade of parliamentary democracy, both political conflict and the resolution of policy issues increasingly takes place within organisations which are unknown to democratic theory' (1980:8). Little has changed since, especially as regards a growing technocratic preference. However, practice is nonetheless argued to have outpaced theory, at least to the degree that recent, empirically-founded studies, although conceding the loss of ideological battles between command interventionism and market-conform supervision, maintain that typological distinctions made between 'autonomous' regulatory models do matter to 
the degree they reflect continuing dispute about the end to which steering capacities are to be exercised within the modern economy (Vibert 2011). In this view, autonomous governance is not synonymous with depoliticization, but is rather the establishment of a 'regulatory enterprise' (Prosser 2010) within which sharp divides between efficiency-led regulation and continuing pursuit of public goods have dissolved within a praxis of discretionary supervision in which all competing rationales are still fought out (Prosser 2010).

This role for national parliaments is appropriate given the potential impact that supervisory measures may have on public finances, credit institutions, their customers and employees, and the markets in the participating Member States (Recital 56, SSM Regulation).

Explaining enhanced lines of reporting within Banking Union to the Council, to the European Parliament and, strikingly so, to national parliaments (Article 21 \& 22 SSM Regulation), the SSM Regulation immediately concedes the distributive - if not re-distributive - character of Banking Union at national level, as well as the potential for its negative impact upon the daily lives of individual Europeans. For all that the ECB is enjoined to act independently from any political influence (Article 19 SSM), a partial politicization of Banking Union is the inevitable consequence of a further diminution of national financial control, and similarly plays a role within ESFS; or does so to the degree that ESA founding regulations, not only provide for parliamentary oversight, but also accord with the new lines of delegation within the EU established by the Lisbon Treaty (Article 290), such that Commission implementing powers are subject to sunset clauses and Council and Parliament recall powers.

Giving credence to studies which stress an empirical fact of the politicisation of modern technocratic governance, for example in enhanced congressional supervision over Basel technocrats (Barr \& Millar 2006), SSM and ESFS politicization nonetheless does not equate with their democratization. Instead, continuing Janus-like tension between technocratic and politicized elements in the governance of sound European money also reflects more deep-seated disjunctions within contemporary perceptions of the appropriate relationship of executive governance to democratic process. At one end of the spectrum, total insulation of expert decision-making from conventional political process is itself argued to be a democratic expression of a will to isolate long-term objectives from political contingency (Majone 1994). However, lying between this position and assertion of direct political oversight, a continuing democratic impulse may also be identified within efforts to secure the transparency, accountability and deliberative quality of EU executive structures and within their subordination to the rule of law. Deriving, not from models of representative legitimation, but rather from more deliberative, participatory and pluralistic theories, the 
democratization of EU technocratic structures nonetheless remains experimental, and therefore fractured, creating - in a final sting of the tail - its own hazards.

\section{Deliberative dissonance and a fractured rule of law}

Key to the deliberation-fostering transparency and accountability of EU permissive-interventionism is the ability of the Council, European and national parliaments to interrogate the innovationstability securing fulcrum of ECB macro-micro supervision. However, where augmented parliamentary oversight now also entails national level review in order to ensure the 'proportionality' and 'subsidiarity' of ECB operation (Recital 56 SSM), history teaches us only that confusion about its exact purposes can result in weaker rather than enhanced supervision of discretionary executive powers. The illustrative example is that of long-standing European Parliament review of ECB monetary policy: urging caution about the results of their quantitative study of Bank-Parliament dialogue, Amtenbrink \& Van Duin (2009) are nonetheless sufficiently confident to highlight the problems arising where parliamentary scrutiny of ECB operation is muddled; in this case, by the question of whether review seeks to assess the quality of ECB monetary performance, or whether, by contrast, it is more concerned with the Bank's role in formulation of EU economic policy. Historically, and despite close co-operation, ${ }^{29}$ parliamentary preoccupation with a 'secondary' ECB task to support EU economic policy (Article 127(1) TFEU) has equally distracted it from review of the technical quality of ECB monetary policy, in a trend which does not 'necessarily point towards an effective scrutiny by the EP of the ECB.'

The core problem has been one of the ECB's continuing attachment to an oversight model which is directed to a review of its monetary competence rather than to its democratic responsiveness: '[T]here is only one criterion on which the ECB [.] will be and should be judged, and that is whether it delivers what it is instituted for, namely price stability. ${ }^{30}$ By the same token, the European Parliament has conceded this technocratic argument, at least to the degree that the 'falling number of inquiries in this regard either suggests that over time the ECB has worn out MEPs in their efforts to have the ECB place more emphasis on its secondary objective, or that MEPs increasingly trust the ECB to make the right assessments and to take the right decisions' (Amtenbrink \& van Duin 2009: 567-568).

Where deliberative dissonance, or cognitive mismatch about the purposes of transparency and reporting requirements are reproduced throughout the sound money regime - for example, where

\footnotetext{
${ }^{29}$ The ECB Chair also appears before specialist committees; a practice developed in addition to a formal annual reporting requirement.

${ }^{30}$ Monetary dialogue of November 9, 1999. Cited in, F.Amtenbrink \& K.Van Duin (2009).
} 
the European Parliament reviews ESA work-programmes ${ }^{31}$ - European and national parliamentary oversight will neither contribute to consensual establishment of an agreed degree of European risk tolerance, nor will it provide effective supervision of the balance struck between security and innovation: the worst of all possible worlds. At the same time, however, potential for deliberative failure within the system is matched and perhaps surpassed by renewed instability within the EU rule of law.

The SSM Regulation is surprisingly detailed in its assessment of the dispute on the degree to which the $E C B$, whose independence from political influence is explicitly guaranteed by Article $130 \mathrm{TFEU}$, is subject to general provisions of European law: '[T]he ECB should carry out its tasks subject to and in compliance with relevant Union law including the whole of primary and secondary Union law, Commission decisions in the area of State aid, competition rules and merger control and the single rulebook applying to all Member States' (Recital 32 SSM Regulation). Drafting caution, however, is perhaps justified in view of the language used by the then European Court of Justice (ECJ), when subjecting the ECB to Union law in the 2000 case of $O L A F .^{32}$ Where AG Jacobs accurately précises the judgment, a degree of legal uncertainty must still arise, at least as regards the Bank's duty to respect any Union law that negatively constrains its primary commitment to price stability:

[T]he Treaty and the Statute confer upon the ECB a high level of independence [.] However, the principle of independence does not imply a total isolation from, or a complete absence of co-operation with, the institutions and bodies of the Community. The Treaty prohibits only influence which is liable to undermine the ability of the ECB to carry out its tasks effectively with a view to price stability, and which must therefore be regarded as undue. ${ }^{33}$

To the degree that the ECB remains attached to its privileged position within the Union as a 'Community within a Community' (Zilioli \& Selmayer 1999:284), and the close two-way relationship between pro-cycliality and monetary policy is accepted, the double-negative within the AG's grammar creates its own potential for legal fragmentation. Must the bank respect Commission Implementing Acts for ESA action, which it considers to encroach upon its monetary competences? Can the ECB release its own corrective regulations, at least within the Eurozone?

\footnotetext{
${ }^{31}$ See note 2 above.

${ }^{32} \mathrm{C}-11 / 00$, Case C-11/00, Commission of the European Communities v European Central Bank. Establishing its own anti-fraud measures and thus failing to recognise Regulation 1073/1999 establishing the Community antifraud body, the ECB asserted a very wide measure of autonomy for itself in relation to the application of Community law, justifying this position with reference to the failure of the TFEU to recognise the ECB as an EU institution, its own legal personality, the independence afforded to the institution (108 TEC), its independent competence to make regulations and take decisions and TFEU failure to subject ECB accounts to review by the Court of Auditors.,

${ }^{33}$ Case C-11/00, note 33, AG Jacobs, paragraph 60.
} 
The potential for a fractured European rule of law may appear remote. However, institutional uncertainty is not confined to Banking Union, but has already emerged within the ESFS, where the legal challenge made by the UK Government to emergency intervention powers afforded the ESMA under MifiD directives was far less surprising than its outcome, in which the CJEU belatedly confirmed direct delegation of EU competence to ESMA and, by association, to each of the three ESAs. At ESFS creation, the long-standing Meroni doctrine of the Court ${ }^{34}$ was thought to preclude full independence of agencies at EU level, which were instead seen as semi-autonomous, independent in fact rather than law, operating under formal Commission competences. The source of the doctrine was the principle of the balance of powers, which the ECJ construed as meaning that executive powers might only be delegated to institutions recognised by European Treaties. As creatures of ad hoc regulatory necessity, agencies had no named place within EU institutional architecture and no formal autonomy. By the same token, the Commission's relations with its own agencies have often been strained to the degree that de facto autonomous agency operations threaten to alienate the competences of a Commission held legally accountable for them.

Institutional uncertainty has accordingly been italicised rather than overcome by the ESMA Judgment, particularly with respect to the Commission's politically-straightened position since the Lisbon Treaty, and consequent potential for mismatch between Commission Implementing Acts and ESA BTS, as well as, ESA emergency actions. Whereas the TFEU now subjects delegation to the Commission of an implementing competence for financial services to temporal constraint and standing recall powers, the sword of Damocles hovers over Brussels heads; meanwhile ESAs with their distanced seats in Frankfurt, London and Paris and now also operating under the direct protection of the Meroni doctrine have assumed their own autonomous competence to intervene directly into national markets.

For the European Commission, ESMA creates a danger that it will be cast as a perpetual loser in an institutional game of competence accrual. By the same token, however, crisis-driven fragmentation of the European executive competence, or the dismantling of the lines of Union delegation that were so recently crafted by the Lisbon Treaty - also by new ECB powers to legislate directly for the Eurozone banking sector (Article 4(2) SSM Regulation) - not only undermines the effort to democratize financial governance from the outset, but also creates important concerns within financial markets that rancour around financial oversight institutions, including a clash of interests between participating and non-participating SSM states, may stoke inefficiency within them. One possible safeguard for markets might be the subordination of the SSM and ESFS to the European

\footnotetext{
${ }^{34}$ Case (9/56) Meroni v High Authority [1957-58] ECR 133.
} 
Charter of Fundamental Rights, in particular, to rights of due process and freedom to conduct a business (Recitals 63 \& 86 SSM Regulation). Assertion of fundamental business rights within the EU, however, remains in its infancy and must likewise be balanced against distorting assertion of political and social rights (Mabett 2011).

\section{Uncertainty, or render unto the market...}

Mismatch between regulatory goals and the profit motive is a constant phenomenon:

The role of a central bank [.] is to minimise the possibility of financial collapse in a system, because the social costs of bank risk-taking exceed the private costs. Private banks, on the other hand, have the objective of maximising profits and shareholder-added-value by taking risks. There is no reason why bank management should be concerned with the social costs of bank failure. Furthermore, if managers demanded that the riskiness of every new product be properly measured from the outset, financial innovation would be non-existent, and the profitability of banks undermined (Heffernan 1996:221-222).

The strict controls applying to traditional banking services just as surely curtailed profitmaximization. Yet, when compared with earlier models, paternalistic in their care for banking consumers, and sometimes greedy in their harnessing of sectoral resources to the purposes of command interventionism, the modern shotgun wedding of the sector to supervisory structures of permissive-interventionism creates its own curious but far-reaching patterns of abuse. Where once prudential regulation was justified by a socio-economic interest in maintenance of effective day-today financial settlements, or by a demand that funds be invested in state bonds or favoured domestic industries for the benefits of the (socialised) nation, it simultaneously established its own politically-curtailed market superstructure within which profit might then be freely pursued. By contrast, contemporary supervision, founded in a vaulting ambition to establish universal welfare gain, reaches deeply into the very psyche of the sector. A national example proves instructive: ${ }^{35}$

That firms should be allowed to fail so long as failure is orderly [.] reflects the view that firms should be allowed to fail, and thereby subject to the disciplines of the market. It is important for firms to be able to fail in an orderly way without public funds being put at risk since, apart from being an unwarranted subsidy, the public provision of solvency support to a firm [.] can create an expectation of future assistance. This 'moral hazard' in turn increases the risk of

\footnotetext{
${ }^{35}$ The Prudential Regulation Authority's approach to Banking Supervision (Bank of England June 2014) available at: www.bankofengland.co.uk/publications/Pages/other/pra/supervisoryapproach.aspx (accessed September 2014), paragraph 21.
} 
future financial instability, as it provides incentives for excessive risk-taking and reduces market discipline.

Explaining its approach to bank failure, the Prudential Regulatory Authority (PRA), the division of the Bank of England responsible for UK oversight within the ESFS, simultaneously enunciates the dominant philosophy of contemporary banking supervision. The PRA demands that banks have a profit-driven risk appetite and expose themselves to failure within a market discipline that simultaneously secures the futurization paradigm. However, 'this risk appetite should similarly be consistent with PRA's objective's' of 'safety and soundness' and the 'continued stability of the financial system. ${ }^{36}$ Any other form of risk appetite - profit motive - is a sinful excess, preferably to be exorcised within the creed of supervisory oversight of bank-internal risk-management, at worst, to be atoned for within a supervised market exit.

We live in a technical age which has made an orchestrated homo economicus of the banking sector: the quantitative modelling of markets for differentiated objects of risk management has largely superseded human judgments made within the firm. Subject also to the desire that they should internalise the risk of potential losses, banks are only further denatured by permissiveinterventionism, as their risk appetites are simultaneously crafted to the prerogatives of financial stability within economic growth. That security in growth is an illusion, matters not a jot. The UK example is again revealing: '[w]hile quantitative models can play an important role in supporting firms' risk management, the PRA expects firms to be prudent in their use of such models given the inherent difficulties with risk measurement. ${ }^{37}$

The post-crisis recognition that risk analysis is not always an objectively-quantitative exercise, but may be skewed at the outset by subjective assumptions - a pertinent example being that a rising market will continue to rise - and, above all, the amplified awareness that some dangers cannot be foreseen, ${ }^{38}$ are perhaps only restatements of the seminal distinction long ago made by Frank Knight between risks and uncertainty (1921). That is, between dangers which can be calculated in probabilistic paradigms (risks), and hazards which defy all statistical accounting (uncertainty). Yet, within the permissive-interventionist paradigm, the radical nature of this statement is obscured, subsumed within a science of manageable risk, wherein the full extent of Knight's careful revelation of the profit motive as an unknowable creature of uncertainty, is discounted, reduced to a systemic

\footnotetext{
${ }^{36}$ Paragraphs $99 \& 97$ PRA, note 45 above.

${ }^{37}$ Paragraph 107, note 45 above.

${ }^{38}$ A realization general to the social sciences, which pre-dates the financial crisis, above all, where dangers posed by physical processes of, e.g., GMOs is subject to concerns about uncertainties such as environmental damage: Asselt \& Vos (2008).
} 
distortion in the perception of risk. By the same token, the post-crisis reiteration of the dominant futurization paradigm, reacts, first, with enhancement of the supervisory function, which reaches its zenith in the elevation of central bankers to a messianic station; and, secondly, through its experimental politicization of the regulatory-governance complex for sound money, thus offering up what is still only a fig leaf of democratic legitimation for the welfare losses that necessarily accompany any trade-off between competitive innovation and financial stability.

The European Union is not alone in the extent of its denial of a Hayekian truth of a market of spontaneously unmanageable human exchange relations. Instead, mainstream political debate in the age of futurization has been remarkable only for its silence about the consequences of the amplified socio-economic expectations that have been levelled at private financial markets following state welfare withdrawal: above all, the inevitability of individual loss due to market failure, but also the difficulties facing the denuded state in the matter of the co-ordination of competing welfare claims. To render unto markets the truth of the uncertainty that is theirs, would appear to be too unpalatable a political utterance. However, within Europe, the attractions of political abdication are only magnified by the material allure of the science of new economic liberalisms, or their promise of value-neutrality in the positing of universal welfare gain within market disciplines, deemed counterfactually - to be a given force of nature.

Brother, 'can you spare a paradigm?' (Hall 2014): ${ }^{39}$ European potential for recovery from a ubiquitous futurization drug is necessarily limited, not simply by its ambition to maintain step with the pace of global financial market change, but also by the difficulties of withdrawal from a narcotic that deadens conflict about the purposes of Union and incommensurability between the interests of its member states. The ESFS and SSM are corollary to the ESM and TSCG, not simply in their preoccupation with a market-driven exit from crisis, but also in their value-neutral foreclosure of a Union-destabilizing space of political alternatives. Nevertheless, just as European peculiarities drive inevitable adoption of the futurization paradigm within a discretionary governance regime for sound European money, they simultaneously heighten insecurity within it. In the short years since ESFS establishment, much has been written about its capacity to amplify uncertainty within European markets, especially as regards the difficulties of co-ordination between binding European standards and their context-dependent national application (Black 2010; Moloney 2011a; Moloney 2011b): how many more hazards will be created by increasing differentiation between the Eurozone and the integrated market? How many new uncertainties will be created by future deliberation failures or challenge to the rule of Union law?

\footnotetext{
${ }^{39}$ Peter Hall, in Governance (26:2, April 2013).
} 
European hubris, belief in the ability of governance steering capacities to reconcile the competing welfare claims of markets, national governments and individual citizens, just as surely finds its apogee in the multiple demands now being made of the ECB. In line with global trends, the bank has, in short measure, been laden with monetary oversight, micro-supervisory functions and the core macro-economic role of balancing competition against stability; albeit that it is still not a lender of last resort. Stated this baldly, the greater surprise is not the extent of political abdication of responsibility for public welfare, but the current reach of miraculous faith in the capacity of any technocratic body - let alone such a relatively youthful organisation, armed only with the legitimation of expert deliberation - successfully to assume this discarded political function.

\section{Bibliography}

Amtenbrink, F. \& K. van Duin, (2009): 'The European Central Bank before the European Parliament: theory and practice after ten years of monetary dialogue', European Law Review 561

Andenas, M. \& H-Y. Chui (2013): 'Financial stability and legal integration in financial regulation' 38(3) European Law Review 335-359

Arnold, B., Borio, C., Ellis, L. \& F. Moshirian (2012): 'Systemic risk: macroprudential policy frameworks, monitoring financial systems and the evolution of capital adequacy,' 36:12 Journal of Banking \& Finance 125-139.

Baldwin, R. and J. Black (2010): 'Really Responsive Risk-Based Regulation' 32:2 Law and Policy 181

Barr, M.S. \& G.P.Millar (2006): 'Global Administrative Law: the view from Basel,' 17(1) European Journal of International Law 15-46.

Black, J. (2010): 'Restructuring Global and EU Financial Regulation: Capacities, Coordination and Learning', LSE Law, Society and Economy Working Papers 18/2010, London School of Economics and Political Science

Block, F. (2013): 'Relational work and the law: recapturing the legal realist critique of market fundamentalism', 40 Journal of Law \& Society $27-48$

Borio, C. \& H. Zhu (2012): 'Capital regulation, risk taking and monetary policy,' 8:4 Journal of Financial Stability 236-251

Born, B., Hermann, M. \& M.Fratzscher (2012): 'Communicating about macro-prudential supervision - a new challenge for central banks,' 15:2 International Finance 179-203.

Buncic, D. \& M. Melecky (2014): 'Equilibrium Credit: The reference point for macroprudential supervisors,' Journal of Banking \& Finance 135-154.

Claeys, S. \& K. Schoors (2007): 'Bank supervision Russian style: Evidence of conflicts between micro- and macro-prudential concerns,' 35:3 Journal of Comparative Economics 630-657.

Crouch, C. (2011): The Strange Non-Death of Neo-Liberalism (Polity Press: London)

E.Ferran \& K.Alexander (2010): Can soft law bodies be effective? The case of the European Systemic Risk Board 35(6) European Law Review 751-776.

Esposito, E. (2013) The Future of Futures: The Time of Money in Financing and Society (Edward Elgar: Cheltenham 2013)

Esposito, E. (2014): 'The Present Use of the Future: Management and Production of Risk on Financial Markets,' in, Luetge, C, and Jauernig, J, (eds) Business Ethics and Risk Management (Springer: Dordrecht)

Everson, M., C. Monda \& E. Vos (eds) (2014): European Agencies in Between Institutions and Member States (Kluwer: Dordrecht 2014)

Garciano, L. \& R.Lastra (2010): Towards a New Architecture for Financial Stability, CEP Discussion Paper No 990 (July 2010), LSE 
Geva, B. (2013), 'Systemic risk and financial stability: the evolving role of the central bank,' 28:10 Journal of International Law and Banking Regulation 403-417

Habermas, J. (2011): 'A Pact for or against Europe?', in U. Guérot and J. Hénard (eds), What does Germany Think about Europe?, (European Council on Foreign Relations: Berlin)

Heffernan, S. (1996): Modern Banking in Theory and Practice (Wiley: London)

Hill, A.A., (2000): 'International banking regulation into the $21^{\text {st }}$ Century: flirting with revolution', (2000) 2:6 Journal of International Financial Markets 216-239

Joerges, Ch. \& J.Neyer (1997): ‘From Intergovernmental Bargaining to Deliberative Political Processes: The Constitutionalisation of Comitology', 3:3 European Law Journal 273-299

Joosen, Bart P.M. (2010): 'The limitations of regulating macro-prudential supervision in Europe,' 25:10 Journal of International Law and Banking Regulation 493-501

Knight, F. (1921): Risk, Uncertainty \& Profit (Houghton \& Mifflin: Boston)

Lee, E. (2013): 'Basel III: post financial crisis international financial regulatory reform,' 28:11 Journal of International Banking Law and Regulation 433-447

Mabbet, D, (2011): 'A Rights Revolution in Europe? Regulatory and judicial approaches to non-discrimination in insurance', (2011) LSE, Europe in Question Discussion Series, no.38/2011.

Majone, G. (1994): 'Independence v accountability: European non-majoritarian institutions and democratic government in Europe,' EUI Working Papers (SPS) 1993/09

Majone, G. (2014): Rethinking the Union of Europe Post-Crisis: Has Integration Gone Too Far? (CUP:Cambridge)

Moloney, N. (2010): 'EU Financial Market Regulation after the Global Financial Crisis: "More Europe" or more Risks?' 47 (5) Common Market Law Review 1317

Moloney, N. (2011a): 'The European Securities and Markets Authority and institutional design for the EU financial market - a tale of two competences: Part 1: rule-making', 12:1 European Business Organization Law Review 41-86

Moloney, N. (2011b): 'The European Securities and Markets Authority and institutional design for the EU financial market - a tale of two competences: Part 2: rules in action' 12:2 European Business Organization Law Review 177

Offe, C. (1980): 'The separation of form and content in liberal democratic politics,' 3 Studies in Political Economy 5-16

Prosser, T. (2011): The Regulatory Enterprise: government regulation and legitimacy (OUP: Oxford)

Sappideen, R. (2004): 'The regulation of credit, market and operational risk management und the Basel Accords,' (Jan) Journal of Business Law 59-93.

Skilos, P.L. (2014): Communication for Multi-Taskers: perspectives on dealing with both monetary policy and financial stability, The Rimini Centre for Economic Analysis, WP 11-04.

Teubner, G. (2011): 'A Constitutional Moment? The Logics of 'Hitting the Bottom', in Poul Kjaer, Gunther Teubner \& Alberto Febbrajo (eds), The Financial Crisis in Constitutional Perspective: The Dark Side of Functional Differentiation (Hart: Oxford), pp9-51.

van Asselt, M. and E.Vos (2008): 'Science, knowledge and uncertainty in EU risk regulation', in M. Everson \& E. Vos (eds), Uncertain Risks Regulated (Routledge-Cavendish 2008).

Vibert, F. (2011): 'Regulation in an age of austerity: Reframing international regulatory policies', LSE Working Paper, WP 03/2011

Zilioli, C. \& M.Selmayer (1999): 'The external relations of the euro legal area: legal aspects (1999) Common Market Law Review 273 